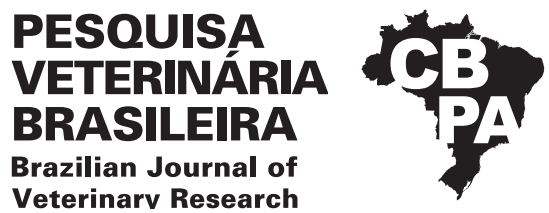

Pesq. Vet. Bras. 41:e06622, 2021

DOI: $10.1590 / 1678-5150-P V B-6622$

Original Article

Veterinarv Research

Livestock Diseases

ISSN 0100-736X (Print)

(cc) BY-NC

ISSN 1678-5150 (Online)

\title{
Prevalence of bovines persistently infected with bovine viral diarrhea virus (BVDV) in dairy cattle herds in Paraná State, Brazil ${ }^{1}$
}

\author{
Bárbara B. Freitas ${ }^{2 *}$ (D), Avelino M.F. Correa ${ }^{3}$, Altair A. Valotto³ ${ }^{3}$ Nicoly N. Marcom \\ Laís R. Paulino ${ }^{2}$, Juliana S. Brum², João H. Perotta ${ }^{2}$ and Ivan R. Barros Filho ${ }^{2}$
}

\begin{abstract}
Freitas B.B., Correa A.M.F., Valotto A.A., Marcom N.N., Paulino L.R., Brum J.S., Perotta J.H. \& Barros Filho I.R. 2021. Prevalence of bovines infected persistently with bovine viral diarrhea virus (BVDV) in dairy cattle herds in Paraná State, Brazil. Pesquisa Veterinária Brasileira 41:e06622, 2021. Departamento de Produção Animal, Universidade Brasil, Avenida Hilário da Silva Passos 950, Parque Universitário, Descalvado, SP 13690-000, Brazil. E-mail: barbarabarbi290@gmail.com

This study aimed to establish the prevalence of animals persistently infected (PI) with bovine viral diarrhea virus (BVDV) in dairy farms at Parana State, Brazil. Samples were collected from 6,465 female Holstein Friesian Dairy Cattle, including animals less than two years old, females over two years old who had not given birth at the farm, and mothers of calves diagnosed as persistently infected. The cattle came from 40 dairy herds distributed in 10 municipalities in the State of Paraná. The samples were obtained from May 2015 to August 2018. The diagnosis of PI animals was made with an antigen-capture ELISA test. We detected PI animals in fifteen herds sampled (37.5\%), ranging from one to sixteen animals per herd. The prevalence in Parana State's municipalities was $1.78 \%$, ranging from 0.3 to $8.9 \%$ at positive herds. The analysis of the individual herds shows significant dissemination of the BVDV in Parana's municipalities, including endemic areas. With this, we highlight the need for measures to raise awareness among producers about the existence and importance of bovine viral diarrhea (BVD) in dairy herds, reinforcing the PI animals' role in disease epidemiology and the economic impact caused by the maintenance of these farm animals.
\end{abstract}

INDEX TERMS: Viral diarrhea virus, BVDV, dairy cattle, herds, Brazil, persistent infection, cattle.

\begin{abstract}
RESUMO.- [Prevalência de bovinos persistentemente infectados com o vírus da diarreia viral bovina (BVDV) em rebanhos leiteiros no estado do Paraná, Brasil.] Com o intuito de se estabelecer a prevalência de animais persistentemente infectados (PI) com o BVDV em propriedades leiteiras no estado do Paraná. Foram coletadas amostras de 6.465 bovinos, fêmeas, da raça Holandês Preto e Branco (HPB). Amostraram-se animais com idade inferior a dois anos, fêmeas com mais de dois anos que não haviam tido partos na propriedade, e mães de bezerros que foram diagnosticados como
\end{abstract}

\footnotetext{
${ }^{1}$ Received on March 5, 2020.

Accepted for publication on September 10, 2020.

${ }^{2}$ Graduate Program in Veterinary Sciences (PPGCV), Universidade Federal do Paraná (UFPR), Setor de Ciências Agrárias, Rua dos Funcionários 1540, Cabral, Curitiba, PR 80035-050, Brazil. *Corresponding author: barbarabarbi290@gmail.com

${ }^{3}$ Associação Paranaense de Bovinos da Raça Holandesa (APBCRH), Rua Prof. Francisco Dranka 608, Orleans, Curitiba, PR 81200-404, Brazil.

${ }^{4}$ Setor de Ciências Agrárias, Departamento de Medicina Veterinária (DMV), Universidade Federal do Paraná (UFPR), Rua dos Funcionários 1540, Cabral, Curitiba, PR 80035-050, Brazil.
}

persistentemente infectados. Os bovinos foram provenientes de 40 rebanhos leiteiros, distribuídos em 10 municípios no Estado do Paraná. A coleta deu-se no período de maio de 2015 a agosto de 2018. 0 diagnóstico dos animais PI foi feito por meio do teste de ELISA de captura de antígeno. Animais PI foram detectados em quinze rebanhos amostrais $(37,5 \%)$, oscilando entre um e dezesseis animais por rebanho. A prevalência nos municípios do estado Paraná foi de 1,78\%, oscilando entre 0,3 a 8,9\% nos rebanhos positivos. Com a alta prevalência de animais PI observada, quando analisados os rebanhos amostrais individualmente, é possível afirmar que há uma disseminação importante do BVDV em municípios paranaenses, destacando inclusive áreas endêmicas. Com isso, vê-se a necessidade de medidas de conscientização dos produtores sobre a existência e importância da BVD nos rebanhos, destacando o papel dos animais PI na epidemiologia da doença, bem como o impacto econômico causado pela manutenção desses animais nos rebanhos.

TERMOS DE INDEXAÇÃO: Diarreia viral bovina, BVDV, rebanhos leiteiros, Brasil, infecção persistente, bovinos. 


\section{INTRODUCTION}

The bovine viral diarrhea virus (BVDV) has a significant economic impact on cattle herds, being endemic in several countries worldwide (Hessman et al. 2009, 2012, Stahl \& Alenius 2012). The virus causes reproductive and productive losses, such as low milk production, abortions, fetal mummification, the birth of weak calves, low conception rates, and increased neonatal mortality (Berends et al. 2008).

Bovine viral diarrhea (BVD) has different clinical presentations, depending on the genotype, biotype, virulence of the viral strain, and the host's susceptibility (Moennig et al. 2005). The infection of a seronegative pregnant cow with non-cytopathic BVDV in the first trimester of gestation, between 40 and 120 days, can result in fetal death or birth of persistently infected (PI) calves (Grooms 2004). PI animals do not present antibodies to BVDV because their immune system recognizes the virus as its own (Arenhart et al. 2009). However, these animals eliminate large amounts of virus in their excretions and secretions throughout their lives. Therefore, they are responsible for introducing and maintaining the virus in herds (Houe 1995).

The properties' greatest difficulty is identifying PI animals since they can be healthy and do not raise any suspicion of their condition (Houe 1993). There is no production of antibodies to BVDV; thus, serological tests to identify them are not useful (Stokstad \& Loken 2002). It is necessary to detect the virus in blood samples or ear fragments to diagnose these animals. The detection methods include direct Enzyme Immunoassay (ELISA), virus isolation, immunoperoxidase, direct immunofluorescence, or Polymerase Chain Reaction preceded by Reverse Transcriptase (RT-PCR) (Flores 2017). Milk tank samples can be collected periodically to determine antibody titers to assess the herd's viral status (Kramps et al. 1999). The detection of high antibody titers may indicate the presence of PI animals in the herd (Houe 2003, Niskanen et al. 1991).

The primary strategy for controlling the disease in herds is identifying and eliminating PI animals (Smith \& Grotelueschen 2004). In European countries, bovine viral diarrhea (BVD) eradication programs were developed based on the diagnosis and elimination of these animals (Thomann etal. 2017, Thulke et al. 2017, Wernike et al. 2017). These programs have shown promising results. However, other measures such as the quarantine period in the introduction of new animals on the farm, as well as evaluation of viral status in the herd, by periodic titration of antibodies in the milk tanks, are also essential for the control of the disease in herds (Kelling et al. 2000).

This study aimed to establish the prevalence of PI animals with BVDV in dairy cattle herds in the State of Paraná, Brazil.

\section{MATERIALS AND METHODS}

This study was approved by the Ethics Committee on the Use of Animals (CEUA) of the "Setor de Ciências Agrárias da Universidade Federal do Paraná", Brazil, under protocol number 102/2017.

Location. The Paraná State is located in the South Region of Brazil $\left(22^{\circ} 29^{\prime} 30^{\prime \prime}\right.$ and $26^{\circ} 42^{\prime} 59^{\prime \prime}$ South latitude, $48^{\circ} 02^{\prime} 24^{\prime \prime}$ and $54^{\circ} 37^{\prime} 38^{\prime \prime}$ West longitude), comprising an area of $199,307 \mathrm{~km}^{2}$. The number of cows milked in Paraná is 1,723,996 heads. The state is the third-largest milk producer in Brazil, and in 2015 the production was 4,730,195 liters, representing $14 \%$ of the milk produced in the country (IBGE 2016). Paraná was chosen as the location of the present study due to its representativeness in the Brazilian dairy sector.
Sampling. Samples were collected from 6,465 female Holstein cattle. Animals under the age of two were sampled, females over two years old who had not given birth on the property, and mothers of calves diagnosed as persistently infected. The cattle came from 40 dairy herds distributed in 10 municipalities in the State of Paraná. Sample collection ranged from May 2015 to August 2018. Figure 1 shows the distribution of the municipalities where the collections were carried out.

The inclusion of the properties in this study depended on the availability and intention of the producer to carry out the diagnosis of animals persistently infected with BVDV, offered by the "Associação Paranaense de Criadores de Bovinos da Raça Holandesa" (APCBRH). These producers chose to perform the diagnosis because of prior suspicion of BVDV infection due to reproductive changes, abortions, and the birth of weak calves on the property. Of 718 properties associated with APCBRH, 40 producers opted for the diagnosis. All properties underwent periodic brucellosis and bovine tuberculosis examinations, vaccination against brucellosis (B19) in females aged three to eight months, and vaccination against foot-and-mouth disease. Table 1 shows the number of herds and samples collected in each municipality.

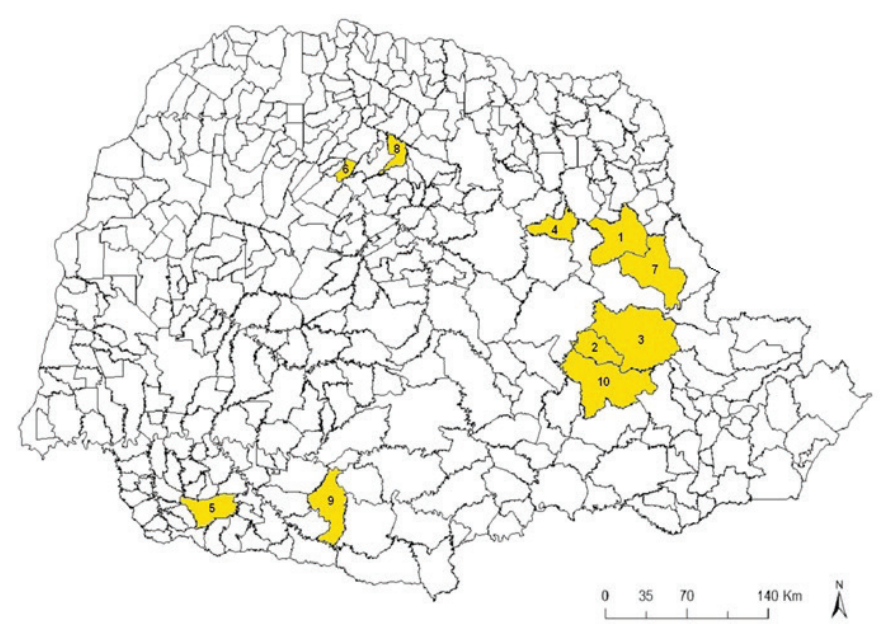

Fig.1. Geographic location of the sampled municipalities in the State of Paraná, Brazil. Arapoti (1), Carambeí (2), Castro (3), Curiúva (4), Francisco Beltrão (5), Floresta (6), Jaguariaíva (7), Mandaguari (8), Mangueirinha (9), Ponta Grossa (10).

Table 1. Distribution of the collection of ear fragment samples for the detection of persistently infected animals with BVDV in municipalities in the state of Paraná, Brazil

\begin{tabular}{lcc}
\hline \multicolumn{1}{c}{ Municipality } & Herds & Animals \\
\hline Arapoti & 5 & 1347 \\
Carambeí & 13 & 3078 \\
Castro & 15 & 1459 \\
Curiúva & 1 & 60 \\
Floresta & 1 & 179 \\
Francisco Beltrão & 1 & 20 \\
Jaguariaíva & 1 & 105 \\
Mandaguari & 1 & 65 \\
Mangueirinha & 1 & 133 \\
Ponta Grossa & 1 & 19 \\
TOTAL & 40 & 6,465
\end{tabular}


Sample. Auricular cartilage fragments were collected, which are relatively stable. The fragments were collected from the ear's tip, with earmarking pliers' aid, and measured approximately three millimeters in diameter. After collection, the fragments were stored in Eppendorf ${ }^{\circledR}$ microtubes at room temperature. The samples were sent to the Diagnostic Laboratory of APCBRH.

Antigen research - direct ELISA. To the microtubes containing the sample, $120-250 \mu \mathrm{L}$ of the IDEXX Ear Notch buffer solution was added. Subsequently, these microtubes were sealed and stored for 24 hours at $26^{\circ} \mathrm{C}$ in a humid chamber.

For the diagnosis of animals persistently infected with BVDV, the IDEXX BVDV Ag/Serum Plus Test ${ }^{\circledR}$ - a direct ELISA test - was used to detect the Erns protein in the sample. In addition to positive and negative controls, $50 \mu \mathrm{L}$ of detection antibodies were added to each well, using a 96-well plate with a micropipette aid.

The plates were shaken slightly to homogenize the contents of the cavities. After homogenization, these plates were sealed to avoid evaporation and incubated for two hours at $37^{\circ} \mathrm{C}$. Subsequently, the plates' contents were removed by washing each well, five times, with $300 \mu \mathrm{L}$ of washing solution. In the last wash, the residual washing fluid was removed from each plate by tapping it lightly. After this washing process, $100 \mu \mathrm{L}$ of the conjugate was added to each well, and the plates were incubated for 30 minutes at $25^{\circ} \mathrm{C}$. Then the washing process described was repeated. Subsequently, $100 \mu \mathrm{L}$ of TMB substrate No. 12 was added to each well, and the plates were incubated again for 10 minutes at $25^{\circ} \mathrm{C}$. At the end of the test, $100 \mu \mathrm{L}$ of "Solução de Interrupção" No. 3 was added to each cavity. The test was read by measuring the absorbance of the samples and controls. According to the manufacturer's guidelines, negative animals were considered to be those with optical density values $<0.2$, suspects $\geq 0.2$ to $<0.3$, and positive $\geq 0.3$.

\section{RESULTS}

Positive herds were detected in three municipalities. The municipalities with the highest sampling showed a higher prevalence. The number of positive animals in the direct ELISA test for antigen detection and the prevalence of PI BVDV cattle per municipality is shown in Table 2. PI animals were

Table 2. Positive animals in the antigen detection test, prevalence of persistently infected animals (\%), quantity and prevalence of positive BVDV herds

\begin{tabular}{lcccc}
\hline \multicolumn{1}{c}{ Municipality } & $\begin{array}{c}\text { Positive } \\
\text { animals }\end{array}$ & $\begin{array}{c}\text { Prevalence } \\
(\%)\end{array}$ & $\begin{array}{c}\text { Positive } \\
\text { herds }\end{array}$ & $\begin{array}{c}\text { Prevalence of } \\
\text { positive herds }\end{array}$ \\
\hline Arapoti & 29 & $\begin{array}{c}2.15 \\
(29 / 1347)\end{array}$ & 4 & $80 \%$ \\
Carambeí & 69 & $\begin{array}{c}2.24 \\
(69 / 3078)\end{array}$ & 7 & $\begin{array}{c}(4 / 5) \\
54 \%\end{array}$ \\
Castro & 17 & 1.16 & 4 & $26.7 \%$ \\
& & $(17 / 1459)$ & & $(4 / 15)$ \\
Curiúva & 0 & 0 & 0 & 0 \\
Floresta & 0 & 0 & 0 & 0 \\
Francisco Beltrão & 0 & 0 & 0 & 0 \\
Jaguariaíva & 0 & 0 & 0 & 0 \\
Mandaguari & 0 & 0 & 0 & 0 \\
Mangueirinha & 0 & 0 & 0 & 0 \\
Ponta Grossa & 0 & 0 & 0 & 0 \\
TOTAL & 115 & 1.78 & 15 & $37.5 \%$ \\
& & & & $(15 / 40)$
\end{tabular}

detected in 15 sample herds (37.5\%), ranging from one to sixteen animals per herd. In the municipality of Arapoti, the prevalence of was $80 \%$ of the sampled herds (4/5), in Carambei $54 \%$ (7/13), and Castro 27\% (4/15). The prevalence values in 14 herds are described in Table 3 . One of the herds is not included in this analysis because only animals considered suspect have been tested.

\section{DISCUSSION}

Studies for the identification of PI animals in Brazil are still scarce, with little data on the dissemination and prevalence of these animals in cattle herds, given the importance they have in the epidemiology of BVD. The choice of diagnosing animals up to two years of age is since PI cattle rarely survive until reproductive age (Stephenson et al. 2017). Given that a calf of a PI female is also affected by PI, the testing of adult females is only immediately necessary when the female does not have a calf in the farm. However, in the case of positive calf, the mother is also tested. Even if the probability of a PI animal reaching the reproductive stage is low, this possibility cannot be ignored, as the calves of a PI female will always be $\mathrm{PI}$, and hardly survive (Khodakaram-Tafti \& Farjanikish 2017).

In the present study, the prevalence of PI animals in the municipalities sampled in Paraná was 1.78\%, ranging from 0.3 to $8.9 \%$ in positive herds. In Goiás, through antigen detection in the direct ELISA test, a prevalence of $0.42 \%$ of PI animals was obtained in 960 sampled cattle (Brito et al. 2010). In western Paraná, Dezen et al. (2013) described a $0.29 \%$ prevalence of PI animals in a herd of 692 cattle using the RT-PCR technique. In the United States, lower prevalence rates are described, such as $0.4 \%$, ranging from 0.06 to $2 \%$ (Fulton et al. 2006); 0.09\% (O'Connor et al. 2007) and 0.2\%, with an interval between 0.03 and $0.9 \%$ (Hoar et al. 2007).

The presence of PI animals in herds represents a negative impact in both the health and economic spheres. The virus can induce immunosuppression, making animals more susceptible to co-infections caused by bacteria, protozoa, and other viruses (Megid et al. 2016). In this way, they are animals that

Table 3. Prevalence (\%) of persistently infected animals with BVDV in dairy cattle herds in municipalities in the state of Paraná, Brazil

\begin{tabular}{lcccc}
\hline Município & Herd & Tested & Positives & Prevalence (\%) \\
\hline Arapoti & 1 & 39 & 3 & 7.7 \\
& 2 & 384 & 1 & 0.3 \\
& 3 & 362 & 10 & 2.8 \\
& 4 & 434 & 15 & 3.5 \\
Carambeí & 5 & 260 & 3 & 1.2 \\
& 6 & 236 & 16 & 6.8 \\
& 8 & 413 & 14 & 3.4 \\
& 9 & 751 & 10 & 1.3 \\
& 10 & 381 & 12 & 2.1 \\
Castro & 11 & 24 & 1 & 3.1 \\
& 12 & 364 & 1 & 4.2 \\
& 13 & 124 & 11 & 0.3 \\
& 14 & 441 & 4 & 8.9 \\
& & & & 0.9
\end{tabular}


get sick with high frequency, generating recurring treatment expenses. Also, PI animals can suffer from mucosal disease and die quickly (Burgstaller et al. 2016).

A study carried out in the United States correlating the weight of cattle with persistent BVDV infection observed that calves weighing less than $180 \mathrm{~kg}$ had a higher prevalence of the infection, being 2.78 times more likely to be PI when compared to calves over $180 \mathrm{~kg}$ (Stephenson et al. 2017). The study above shows that these animals show underdevelopment and less weight gain compared to healthy animals. Exposure to BVDV can reduce the conception rate, abortions, and a drop in milk production (Houe 2003). Besides, there is research in Norway reporting a $7 \%$ increase in clinical mastitis incidence in herds exposed to BVDV (Waage 2000).

In the present study, the prevalence of herds with PI animals' presence was $37.5 \%$ (15/40). In a study in New Zealand, the prevalence of PI cattle was estimated at $14.6 \%$ of the herds (Thobokwe et al. 2004). In the United States, a prevalence of $3 \%$ in herds selected at random and 19\% in herds suspected of being infected with BVDV was described in five American states (Wittum et al. 2001). In Belgium, the identification of PI animals was carried out in different regions, with prevalence in $32 \%$ of the sampled herds in the North and $13 \%$ in the South (Letellier et al. 2005). These data demonstrate that, in the present study, the prevalence was much higher than those described in other countries. This fact may be associated with all sampled herds being suspected of being infected by BVDV due to the history of reproductive changes, abortions, and weak calves' birth.

The same was observed by Wittum et al. (2001), in which suspicious herds had a higher occurrence of PI animals than herds randomly chosen. This fact demonstrates the importance of making the diagnosis based on history, clinical and epidemiological signs. The BVD has several clinical presentations, and enteric, respiratory, or reproductive changes can occur (Lima et al. 2004), leading to errors in diagnosis by ruling out the possibility of BVDV infection if not all of these signs are present. Therefore, the search for PI animals must be done on properties with any of the presentations described.

However, it is essential to consider that Brazil does not have programs to control and eradicate BVD, contributing to the higher prevalence values. Germany has had a BVD eradication program since 2011, defined by the identification of PI animals and their elimination from herds. With this program, the country had a reduction of properties with a prevalence of PI cattle from $3.44 \%$ in 2011 to just $0,16 \%$ in 2016 (Wernike et al. 2017). It is noted how eradication programs can contribute to the reduction of BVD in herds.

The data obtained in this research differ from other studies in Brazil and other countries, which may be related to the larger sample size concerning other studies and the diagnostic method used. The method used by some authors is considered more accurate by the identification of viral RNA. In a study carried out in Poland comparing the ELISA-Ag based on the Erns protein - a structural protein -, the Realtime RT-PCR (qRT-PCR), and the ELISA-Ag test based on the NS3 protein - a non-structural protein - it was observed that it was possible to identify PI animals in $89.7 \%, 100 \%$ and $3.4 \%$ of cases, respectively (Larska et al. 2013). Similarly, a previous study has described the superiority of RNA detection regarding ELISA on the presence of maternal antibodies (Zimmer et al. 2004).

A study by Fulton et al. (2006) states that there is no statistical difference between the ELISA-Ag, Immunohistochemistry (IHC), and RT-PCR tests. The study also emphasizes the practicality and safety of the ELISA and individual results compared to RT-PCR, where samples can be pools. For the present authors, the ELISA test is an effective method for identifying PI animals. However, the diagnosis must be made before colostrum or in the period of reduction of maternal antibodies, as they may interfere with the test result. This time of reduction is after 30 days of age, but it also depends on the number of immunoglobulins present in maternal colostrum, making the period longer (Tizard 2014).

A higher prevalence of PI animals was observed in Arapoti, Castro, and Carambeí regarding the others sampled. According to Houe (2003), it is estimated that in an endemic region, the number of PI animals is around $2 \%$, information that draws attention given the results obtained in this research. It can be considered that the regions of the municipalities of Arapoti and Carambeí are characterized as endemic areas for the BVDV.

These municipalities are located in the largest milk basin in Paraná, with Castro being the largest milk producer in the country. The average milk production in the region is 5,243 liters/cow/year, exceeding the national average of 1,480 liters/cow/year (IBGE 2016). This factor indicates that this region's properties have more intensive production systems, with larger feedlots and larger herds. According to Van Campen (2010), the larger the herd, the more attention to biosafety and sanitation measures becomes insufficient, contributing to the virus's presence and circulation in the herd. It is noteworthy the impact that the spread of BVDV by PI animals' presence may represent for these municipalities.

The diagnosis and elimination of PI animals, quarantine period in the acquisition of animals, and vaccination programs are the most efficient control measures for the virus (Ferro et al. 2017, Letellier et al. 2005, Smith \& Grotelueschen 2004).

\section{CONCLUSIONS}

With the high prevalence of PI animals observed, when analyzing the sample herds individually, we observed important dissemination of the BVDV in Paraná municipalities, highlighting even endemic areas.

Considering that APCBRH is the first association of breeders to make this service available, in addition to the small number of producers who have been interested in making the diagnosis, it is a strategy that is moving slowly in Brazil.

There is a need for measures to raise awareness among producers about the existence and importance of BVD in herds, highlighting the role of PI animals in the disease's epidemiology and the economic impact caused by the maintenance of these animals in herds.

Conflict of interest statement.- The authors have no competing interests.

\section{REFERENCES}

Arenhart S., Bauermann F.V., Oliveira S.A.M., Weiblen R. \& Flores E.F. 2009. Excreção e transmissão do vírus da diarreia viral bovina por bezerros persistentemente infectados. Pesq. Vet. Bras. 29(9):736-742. <https:// dx.doi.org/10.1590/S0100-736X2009000900010> 
Berends I.M.G.A., Swart W.A.J.M., Frankena K., Muskens J., Lam T.J.G.M. \& Van Schaik G. 2008. The effect of becoming BVDV-free on fertility and udder health in Dutch dairy herds. Prev. Vet. Med. 84(1/2):48-60.<https://dx.doi. org/10.1016/j.prevetmed.2007.11.002><PMid:18155307>

Brito W.M.E.D., Alfaia B.T., Caixeta S.P.M.B., Ribeiro A.C.C., Miranda T.M.T., Barbosa A.C.V.C., Barthasson D.L., Linhares D.C. \& Faria B.O. 2010. Prevalência da infecção pelo vírus da diarreia viral bovina (BVDV) no estado de Goiás, Brasil. J. Trop. Pathol. 39(1):7-19.<https://dx.doi.org/10.5216/rpt.v39i1.9494>

Burgstaller J., Obritzhausar W., Kuchling S., Kopacka I., Pinior B. \& Kofer J. 2016. The effect of bovine viral diarrhoea virus on fertility in dairy cows: two case-control studies in the province of Styria, Austria. Berl. und Munch Tierarztl. Wochenschr. 129(3/4):103-110. <PMid:27169147>

Dezen S., Otonel R.A.A., Alfieri A.F., Lunardi M. \& Alfieri A.A. 2013. Perfil da infecção pelo vírus da diarreia viral bovina (BVDV) em um rebanho bovino leiteiro de alta produção e com programa de vacinação contra o BVDV. Pesq. Vet. Bras. 33(2):141-147. <https://dx.doi.org/10.1590/ S0100-736X2013000200002>

Ferro P.J., Fearneyhough M.G., Calvert C., Neill J. \& Ridpath J.F. 2017. Case report: Emergence of bovine viral diarrhea virus persistently infected calves in a semi-closed herd. Bov. Pract. 50(1):28-30. <https://dx.doi. org/10.21423/bovine-vol50no1p28-30>

Flores E.F. 2017. Virologia Veterinária: virologia geral e doenças víricas. UFSM, Santa Maria, p.577-591.

Fulton R. W., Hessman B., Johnson B.J., Ridpath J.F., Saliki J.T., Burge L.J., Sjelocha D., Confer A.W., Funk R.A. \& Payton M.E. 2006. Evaluation of diagnostic tests used for detection of bovine viral diarrhea virus and prevalence of subtypes $1 \mathrm{a}, 1 \mathrm{~b}$, and $2 \mathrm{a}$ in persistently infected cattle entering a feedlot. J. Am. Vet. Med. Assoc. 228(4):578-584. <https://dx.doi.org/10.2460/ javma.228.4.578><PMid:16478438>

Grooms D.L. 2004. Reproductive consequences of infection with bovine viral diarrhea virus. Vet. Clin. N. Am., Food Anim. Pract. 20(1):5-19. <https://dx.doi.org/10.1016/j.cvfa.2003.11.006> <PMid:15062471>

Hessman B.E., Fulton R.W., Sjeklocha D.B., Murphy T.A., Ridpath J.F. \& Payton M.E. 2009. Evaluation of economic effects and the health and performance of the general cattle population after exposure to cattle persistently infected with bovine viral diarrhea virus in a starter feedlot. Am. J. Vet. Res. 70(1):73-85.<https://dx.doi.org/10.2460/ajvr.70.1.73><PMid:19119951>

Hessman B.E., Sjeklocha D.B., Fulton R.W., Ridpath J.F., Johnson B.J. \& McElroy D.R. 2012. Acute bovine viral diarrhea associated with extensive mucosal lesions, high morbidity, and mortality in a commercial feedlot. J. Vet. Diag. Invest. 24(2):397-404. <https://dx.doi.org/10.1177/1040638711436244> <PMid:22379057>

Hoar B.R., McQuarry A.C. \& Hietala S.K. 2007. Prevalence of Neospora caninum and persistent infection with bovine viral diarrhea virus in dairy-breed steers in a feedlot. J. Am. Vet. Med. Assoc. 230(7):1038- 1043. <https://dx.doi.org/10.2460/javma.230.7.1038><PMid:17397345>

Houe H. 1993. Survivorship of animals persistently infected with bovine virus diarrhoea virus (BVDV). Prev. Vet. Med. 15(4):275-283. <https://dx.doi. org/10.1016/0167-5877(93)90099-F>

Houe H. 1995. Epidemiology of Bovine Viral Diarrhea Virus. Vet. Clin. N. Am., Food Anim. Pract. 11(3):521-547. <https://dx.doi.org/10.1016/ s0749-0720(15)30465-5><PMid:8581861>

Houe H. 2003. Economic impact of BVDV infection in dairies. Biologicals 31(2):137-143. <https://dx.doi.org/10.1016/s1045-1056(03)00030-7> <PMid:12770546>

IBGE 2016. Produção da Pecuária municipal 2015. Instituto Brasileiro de Geografia e Estatística, Rio de Janeiro.

Kelling C., Grotelueschen D.M., Smith D.R. \& Brodersen B.W. 2000. Testing and management strategies for effective beef and dairy herd BVDV biosecurity programs. Bov. Pract. 34(1):13-22. <https://dx.doi.org/10.21423/bovinevol34no1p13-22>
Khodakaram-Tafti A. \& Farjanikish G.H. 2017. Persistent bovine viral diarrhea virus (BVDV) infection in cattle herds. Iranian J. Vet. Res. 18(3):154-163. <PMid:29163643>

Kramps J.A., Van Maanen C., Van Wetering G., Stienstra G., Quak S., Brinkhof J., Ronsholt L. \& Nylin B. 1999. A simple, rapid and reliable enzymelinked immunosorbent assay for the detection of bovine virus diarrhea virus (BDVD) specific antibodies in cattle serum, plasma and bulk milk. Vet. Microbiol. 64(2/3):135-144. <https://dx.doi.org/10.1016/s03781135(98)00265-x><PMid:10028168>

Larska M., Kuta A. \& Polak M.P. 2013. Evaluation of diagnostic methods to distinguish between calves persistently and transiently infected with bovine viral diarrhoea virus in respect to the presence of maternal antibodies. Bull. Vet. Inst. Pulawy 57(3):311-317. <https://dx.doi.org/10.2478/ bvip-2013-0054>

Letellier C., De Meulemeester L., Lomba M., Mijten E. \& Kerkhofs P. 2005. Detection of BVDV persistently infected animals in Belgium: evaluation of the strategy implemented. Prev. Vet. Med. 72(1/2):121-125. <https:// dx.doi.org/10.1016/j.prevetmed.2005.08.009> <PMid:16169612>

Lima M., Flores E.F., Weiblen R., Vogel F.S.F. \& Arenhart S. 2004. Caracterização de amostras atenuadas do vírus da diarreia viral bovina (BVDV) tipos 1 e 2 para uso em vacinas. Pesq. Vet. Bras. 24(1):35-42. <https://dx.doi. org/10.1590/S0100-736X2004000100009>

Megid J., Ribeiro M.G. \& Paes A.C. 2016. Doenças Infecciosas em animais de produção e de companhia. Roca, Rio de Janeiro, p.587-597.

Moennig V., Houe H. \& Lindberg A. 2005. BVD control in Europe: current status and perspectives. Anim. Health Res. Rev. 6(1):63-74. <https:// dx.doi.org/10.1079/ahr2005102> <PMid:16164009>

Niskanen R., Alenius S., Larsson B. \& Jacobsson S.O. 1991. Determination of level of antibodies to bovine virus diarrhoea virus (BVDV) in bulk tank milk as a tool in the diagnosis and prophylaxis of BVDV infections in dairy herds. Arch. Virol. (Supl.3):245-251. <https://dx.doi.org/10.1007/9783-7091-9153-8_30><PMid:9210948>

0'Connor A.M., Reed M.C., Denagamage T.N., Yoon K-J., Sorden S.D. \& Cooper V.L. 2007. Prevalence of calves persistently infected with bovine viral diarrhea virus in beef cow-calf herds enrolled in a voluntary screening project. J. Am. Vet. Med. Assoc. 230(11):1691-1696. <https://dx.doi.org/10.2460/ javma.230.11.1691 > <PMid:17542740>

Smith D.R. \& Grotelueschen D.M. 2004. Biosecurity and biocontainment of bovine viral diarrhea virus. Vet. Clin. N. Am., Food Anim. Pract. 20(1):131149. <https://dx.doi.org/10.1016/j.cvfa.2003.11.008><PMid:15062479>

Stahl K. \& Alenius S. 2012. BVDV control and eradication in Europe - an update. Japan J. Vet. Res. 60(Supl.):31-39. <PMid:22458198>

Stephenson M.K., Palomares R.A., White B.J., Engelken T.J. \& Brock K.V. 2017. Prevalence of bovine viral diarrhea virus (BVDV) persistently infected calves in auction markets from the southeastern United States; association between body weight and BVDV-positive diagnosis. Prof. Anim. Scient. 33(4):426-431. <https://dx.doi.org/10.15232/pas.2017-01619>

Stokstad M. \& Loken T. 2002. Pestivirus in cattle: Experimentally induced persistent infection in calves. J.Vet. Med., Series B 49(10):494-501.<https:// dx.doi.org/10.1046/j.1439-0450.2002.00600.x><PMid:12485360>

Thobokwe G., Heuer C. \& Hayes D. P. 2004. Validation of a bulk tank milk antibody ELISA to detect dairy herds likely infected with bovine viral diarrhoea virus in New Zealand. New Zealand Vet. J. 52(6):394-400. <https://dx.doi.org/10.1080/00480169.2004.36457><PMid:15768141>

Thomann B., Tschopp A., Magouras I., Meylan M. \& Schüpbach-Regula G. 2017. Economic evaluation of the eradication program for bovine viral diarrhea in the Swiss dairy sector. Prev. Vet. Med. 145:1-6. <https://dx.doi. org/10.1016/j.prevetmed.2017.05.020 > <Mid:28903865>

Thulke H.H., Lange M., Tratalos J.A., Clegg T.A., McGrath G., O'Grady L., O'Sullivan P., Doherty M.L., Graham D.A. \& More S.J. 2017. Eradicating BVD, reviewing Irish programme data and model predictions to support 
prospective decision making. Prev. Vet. Med. 150:151-161. <https://dx.doi. org/10.1016/j.prevetmed.2017.11.017><PMid:29221591>

Tizard I.R. 2014. Imunologia Veterinária: uma introdução. 9ª ed. Elsevier, Rio de Janeiro, p.490-520.

Van Campen H. 2010. Epidemiology and control of BVD in the U.S. Vet. Microbiol. 142(1/2):94-98. <https://dx.doi.org/10.1016/j.vetmic.2009.09.049> $<$ PMid:19833455>

Waage S. 2000. Influence of new infection with bovine virus diarrhoea virus on udder health in Norwegian dairy cows. Prev. Vet. Med. 43(2):123-135. <https://dx.doi.org/10.1016/S0167-5877(99)00084-7>
Wernike K., Gethmann J., Schirrmeier H., Schröder R., Conraths FJ. \& Beer M. 2017. Six years (2011-2016) of mandatory nationwide bovine viral diarrhea control in Germany - a success story. Pathogens 6(4):50. <https://dx.doi. org/10.3390/pathogens6040050 > <Mid:29057796>

Wittum T.E., Grotelueschen D.M., Brock K.V., Kvasnicka W.G., Floyd J.G., Kelling C.L. \& Odde K.G. 2001. Persistent bovine viral diarrhoea virus infection in US beef herds. Prev. Vet. Med. 49(1/2):83-94. <https://dx.doi.org/10.1016/ s0167-5877(01)00181-7><PMid:11267691>

Zimmer G.M., Van Maanen C., De Goey I., Brinkhof J. \& Wentink G.H. 2004. The effect of maternal antibodies on the detection of bovine virus diarrhoea virus in peripheral blood samples. Vet. Microbiol. 100(3/4):145-149. <https://dx.doi.org/10.1016/j.vetmic.2004.03.008> <PMid:15145493> 